\title{
ЕСТЕТИЧНА СУТНІСТЬ ТА СПЕЦИФІКА КОРЕКЦІЙНО-ПЕДАГОГІЧНОЇ ПРАЦІ ДЕФЕКТОЛОГА
}

\author{
доктор педагогічних наук, професор Демченко I. I., \\ кандидат педагогічних наук, дочент Білан В. А., \\ кандидат педагогічних наук, доцент Бабій I. В., \\ викладач Черніченко Л. А.
}

Украйна, м. Умань, Уманський державний педагогічний університет імені Павла Тичини, кафедра спеціальної освіти

DOI: https://doi.org/10.31435/rsglobal_ws/31052019/6526

\section{ARTICLE INFO}

Received: 06 March 2019

Accepted: 10 May 2019

Published: 31 May 2019

\section{KEYWORDS}

a special education teacher, aesthetics of work, correctionpedagogical work, correctionpedagogical technology, aesthetic and therapeutic competence.

\begin{abstract}
In the article the problem of increase of efficiency of professional preparation of a special education teacher is analysed, the meaning of the concept "Correction-pedagogical work" is defined, the essence of work of a special education teacher is grounded, the functions of its aesthetic and therapeutic competence are exposed, and also the aesthetic aspect of correction-pedagogical technology of communication of a special education teacher with children with special educational needs.
\end{abstract}

Citation: Демченко I. І., Білан В. А., Бабій І. В., Черніченко Л. А. (2019) Estetychna Sutnist ta Spetsyfika Korektsiino-Pedahohichnoi Pratsi Defektoloha. World Science. 5(45), Vol.3. doi: 10.31435/rsglobal_ws/31052019/6526

Copyright: (C) 2019 Демченко І. І., Білан В. А., Бабій І. В., Черніченко Л. А. This is an open-access article distributed under the terms of the Creative Commons Attribution License (CC BY). The use, distribution or reproduction in other forums is permitted, provided the original author(s) or licensor are credited and that the original publication in this journal is cited, in accordance with accepted academic practice. No use, distribution or reproduction is permitted which does not comply with these terms.

Вступ. На початку третього тисячоліття проблеми виховання, освіти і розвитку молодого покоління набувають особливого значення, зокрема спеціальної освіти. Щоб освіта стала справді людиноперетворювальною, вона повинна бути звернена до «внутрішніх сфер» особистості. Для цього людині важливо розуміти й сприймати себе, визначати перспективи власного розвитку, бачити й використовувати власні інтелектуальні, емоційні, духовноморальні резерви, засоби самоактивізації й самовдосконалення. Саме тому в умовах інтеграції системи освіти України в світовий освітній простір, що регламентується нормативними документами Болонського процесу, особливо актуальною постає проблема підвищення ефективності професійної підготовки майбутніх фахівців гуманітарного профілю, зокрема, педагогів-дефектологів. Тому, що забезпечення повноцінного розвитку дітей 3 вадами знаходяться у прямій залежності від рівня компетентності педагогів дефектологів. Саме тому сьогодні важливо не зупинятися у пошуках того, якого вчителя має готувати вища школа, якими професійними якостями і здібностями повинні володіти працівники освіти, покликані готувати молоде покоління до завтрашніх днів.

У системі сучасної педагогічної освіти в Україні нагромаджено значний теоретичний $\mathrm{i}$ практичний досвід розв'язання численних завдань естетичного виховання майбутніх учителів різного фаху. Про це свідчать наукові праці В. Бутенка, М. Лещенко, Л. Масол, Г. Падалки та інших учених. У зв'язку із зазначеним вище виявляється доцільним осмислення питання про естетичну компетентність вчителя, наявність у нього досвіду, спроможного вивести його працю на рівень освоєння дійсності за законами краси, гармонії, виразності, цілісності тощо. 
Аналіз останніх досліджень і публікацій. Проблема вдосконалення професійної підготовки педагога-дефектолога корекційної освіти широко розроблялась і розробляється у корекційній педагогіці. Вона $є$ предметом дослідження багатьох вчених, зокрема: Р. Агавелян, В. Бородіна, I. Бгажнокова, I. Єременко, С. Забрамної, В. Кащенко, І. Колесника, М. Кота, С. Миронової, Н. Назарова, Л. Одинченко, Ю. Пінчук, Л. Руденко, В. Селіверстова, В. Синьова, 3. Смирнова, О. Черкасова, А. Шевцова, М. Шеремет, Л. Шипіцина та ін., проте питання якісної підготовки фахівців вимагають вдосконалення підготовки.

Специфіка трудової діяльності педагога-дефектолога ставить особливі вимоги до самого педагогічного процесу та його результату, високий рівень естетики яких залежить від добре налагоджених гуманних взаємин. Тому особливої уваги заслуговують естетичні вияви корекційно-педагогічної праці дефектолога.

Мета дослідження. Розкрити поняття «технологія», «корекційно-педагогічна технологія», «корекційно-педагогічна праця» та досліджено естетичну сутність корекційнопедагогічної праці дефектолога.

Результати дослідження. Україна нині перебуває на стадії серйозних суспільноекономічних змін. Кожна соціальна категорія відчуває на собі складність змін. Дослідники одностайні в тому, що найбільш уразливими залишаються найменш захищені представники українського суспільства - пенсіонери та діти з особливостями психофізичного розвитку. Тому актуальним на сьогодні є розв'язання широкого спектру проблем навчання і виховання дітей 3 вадами психофізичного розвитку.

Проблема здобуття освіти дітьми 3 особливостями психофізичного розвитку інтердисциплінарна. У вітчизняній науці їй присвячено багато грунтовних студій. Зокрема, А. А. Колупаєва, Л. О. Савчук у рамках канадсько-українського проекту «Інклюзивна освіта для дітей з особливими потребами в Україні» проаналізували теоретичне підгрунтя інклюзивної освіти, роль батьків у соціалізації дитини, окреслили специфіку корекційно-розвивальної роботи та проблеми індивідуального навчання в контексті модернізації освіти. «Найскладнішою, зазначають автори, - $є$ проблема ізоляції дитини від соціального оточення, формування комунікації та мотивації до будь-якої активної діяльності. Тому основним завданням педагогів $\epsilon$ розробити оптимальну модель системи надомного навчання, яка б включала в себе розділи психокорекції та реабілітації й певним чином забезпечувала інтегрування дитини в загальноосвітній простір», для чого пропонують алгоритм організації надомного навчання.

Нагорна О. Б. в посібнику «Особливості корекційно-виховної роботи 3 дітьми 3 особливими освітніми потребами» докладно зупинилася на питаннях діагностики дітей 3 особливими освітніми потребами, проаналізувала специфіку розвитку дітей із ДЦП та синдромом Дауна, запропонувала здоров'язберігаючі технології, що підвищать ефективність навчання таких дітей, окреслила шляхи співпраці школи та батьків у вирішенні цієї проблеми. Авторка висновує: «внаслідок залучення батьків до навчально-корекційної роботи сім'я та дитина отримують скоординовану, сплановану, всебічну кваліфікаційну допомогу. Дитина виховується в сім’ї, розвивається згідно з власним потенціалом, батьки здатні самостійно виховувати дитину з порушенням психомоторного розвитку. Входження дитини в коло своїх однолітків може сприяти поступовій зміні і психічного стану їхніх батьків - послаблюватиме напруженість, покращуватиме емоційний стан, підвищуватиме ефективність навчальновиховної, реабілітаційно-корекційної роботи. Активна, вмотивована, ціннісно-зорієнтована і педагогічно керована участь батьків у навчально-виховному процесі буде обумовлювати зменшення їхніх тривог і страхів, мобілізуватиме сили на щоденне і перспективне досягнення успіху, по-новому структуруватиме світосприйняття цілої родини, близьких до неї людей» [5].

Нагорна О. Б., Чернієнко О.А. переконані, що для забезпечення комплексного корекційного впливу на дитину з особливими освітніми потребами «доцільним є створення міждисциплінарної команди, яка об'єднуватиме освітян, корекційних фахівців, медиків та батьків для формування ефективного та безперервного освітньо-реабілітаційного простору. Члени міждисциплінарної команди забезпечать реабілітаційно-оздоровчий супровід дитини упродовж всього підготовчого періоду до школи та протягом молодшого шкільного віку: однолітками;

- логопед корегує мовленнєвий розвиток, який дозволить дитині спілкуватися 3

- педагог здійснює навчально-виховний, навчально-корекційний вплив; 
- реабілітолог забезпечує встановлення можливостей і шляхів компенсації порушень різної складності, виявлення механізмів корекції вторинних відхилень, розвиток навичок самообслуговування, корекційно-розвитковий та реабілітаційно-оздоровчий процес;

- завданням психолога $€$ розвиток комунікативної сфери, формування позитивних рис особистості, адекватної самооцінки та необхідного рівня домагань» [1, с. 23].

Тому праця педагога-дефектолога виходить за межі традиційних видів роботи вчителя, оскільки охоплює: консультаційну, діагностичну, соціально-педагогічну, реабілітаційну, психотерапевтичну та корекційну діяльність. Ця багатогранність підпорядкована меті професійної діяльності педагога-дефектолога: йдеться про соціальну адаптацію та інтеграцію дитини з особливими освітніми потребами у систему суспільних стосунків. Для реалізації цієї мети всі компоненти педагогічної діяльності дефектолога мають бути корекційно спрямованими, а власне корекційна робота - виділятись у специфічний вид діяльності. Тому творчість, майстерність, мистецтво, етика й естетика - це провідні складники високої якості будь-якої конструктивної діяльності. У корекційно-педагогічній праці дефектолога вони втілюють у собі доцільність і красу виховних впливів на особистість дитини. «Естетична форма й естетичний зміст, як справедливо стверджує Я. Сспаєв, їх єдність і розмаїття яскраво й поглиблено виявляються в усій професійних сферах діяльності педагога: у гностичній, проектувальній, конструктивній, організаторській і комунікативній» [6]. Учений переконаний, що естетика праці педагога має три рівні - краса особистого прикладу, естетика виховного процесу та його результатів. Ця тріада грунтується на гармонії й цілісності, прекрасному й піднесеному. Із цієї позиції правомірно стверджувати, що корекційно-педагогічна діяльність дефектолога як процесуальний вид праці базується на мовних актах, у яких естетичне полягає в красі слова, інтонації, жестів, міміки, поз тощо.

Видатний вітчизняний театральний діяч К. Станіславський писав: «Театр - двосічний меч, однією стороною він бореться в ім'я світла, іншою - в ім'я пітьми. 3 тією силою впливу, 3 якою театр ушляхетнює глядачів, він може розбещувати їх, принижувати, псувати смаки, ображати чистоту, збуджувати дурні пристрасті, слугувати вульгарності і маленькій міщанській красивості» [1]. Аналогічний подвійний (позитивний і негативний) вплив на особистість вихованця може здійснювати й дефектолог - скоригувати фізичні чи психічні вади дитини, або посилити їх. Конструктивна функція його праці вимагає специфічних рис іï організації на основі загальних принципів естетики (прекрасне, піднесене, героїчне тощо), завдяки чому розвивається особливе ставлення до дітей, що виражається насамперед у любові. Деструктивна функція, за словами Б. Ліхачова, полягає у відсутності гармонії змісту педагогічного процесу, форм і методів організації дитячого життя, унаслідок чого виявляється педагогічне безсилля, виникає потворне як свідчення помилковості стосунків дітей i дорослих [1]. Учений переконливо довів, що найвиразнішим критерієм істинності навчально-виховних систем $€$ внутрішня гармонія, чистота, краса самої дитячої особистості, що, з позиції результативності корекційно-педагогічної праці, «...знаходить своє вираження в зовнішньому вигляді: у привабливості зовнішніх рис, у вираженні духовності й людяності на обличчі» [3].

Специфіка трудової діяльності дефектолога ставить особливі вимоги до самого педагогічного процесу та його результату, високий рівень естетики яких залежить від добре налагоджених гуманних взасмин, оскільки діти 3 порушеннями в розвитку найчастіше позбавлені ласки, тепла й турботи з боку оточуючих.

Вагомим інструментом педагогічної діяльності дефектолога для налагодження гуманних взаємин більшість дослідників (А. Бодальов, Л. Виготський, В. Кан-Калик, А. Мудрик, А. Щербаков та ін.) виокремлюють педагогічне спілкування, що в естетичному контексті повинно викликати у вихованців піднесений настрій, радощі пізнання й прагнення творити за законами краси. Саме тому, як зазначає Е. Сегена, дефектолог має відрізнятися гарними манерами, виразною мовою й жестами, що змушують дитину звернути на нього увагу, слухати, бачити, визнавати й довіряти йому.

Однак постає необхідність обгрунтувати термін «корекційно-педагогічна праця».

У науково-педагогічній літературі найпоширенішими $є$ поняття «корекційно-педагогічна діяльність», «корекційно-педагогічна робота», корекційно-педагогічний супровід», «корекційнопедагогічна допомога» тощо. Безперечно, кожне з них охоплює певну міру активності дефектолога в педагогічній праці. У дослідженні Т. Окушко категорію «корекційно-педагогічна діяльність» потрактовано як «певним чином спланований та організований навчально-виховний процес, що реалізується з підлітками, метою якого є не тільки виправлення існуючих відхилень у поведінці, а й 
створення передумови щодо подальшого розвитку, позитивної соціалізації та інтеграції їх у соціум» [3, с. 13]. Таке узагальнене визначення може стосуватися кожного з наведених словосполучень. Тому ми вважаємо, що їх доцільно об’єднати в єдину категорію «корекційно-педагогічна праця», під якою слід розуміти цілеспрямовану систему дій, операцій, вчинків і впливів дефектолога на особистість дитини 3 недоліками навчання, виховання й вадами розвитку для їх усунення, подолання й подальшої гармонізації фізичної, психічної, інтелектуальної й творчої сфер 3 адекватним використанням та постійним збагаченням фонду ефективних педагогічних форм, методів, засобів, прийомів і технологій навчання, виховання й міжособистісної взаємодії. Обгрунтованість нашої позиції аргументована тим, що за Є. Климовим, лише ту активність суб'єкта доцільно називати працею, що характеризується свідомим передбаченням соціально-ціннісного результату, обов'язковості досягнення фіксованої мети, вибору, пристосуванню, удосконаленню й створенню знарядь праці та ії засобів, а також усвідомлення міжлюдських виробничих відносин. Як бачимо, вимальовується певна цілісність, що складається з суб'єкта праці, ії предмета, засобів та виробничого середовища. Ми впевнені, що така система має бути наповнена естетичним змістом: фізична й духовна краса педагога та його вихованців, досконалість та ергономічність трудових засобів і якісний дизайн предметного середовища, у якому відбувається педагогічна взаємодія. Це підтверджується тезою А. Маркової про те, що праця педагога є системою, котра має триєдину структуру: педагогічна діяльність, педагогічне спілкування й особистість. У площині професіоналізму дефектолога це особливо увиразнюється. Якщо взяти до уваги те, що предметом його праці є діти з певними вадами, котрі нерідко сприймаються в світлі трагічного, потворного й комічного, то його естетико-творча місія полягає в доборі й постійному оновленні щонайширшого спектру форм, методів, прийомів і засобів педагогічної корекції (арт-терапевтичні, етнотерапевтичні, природотерапевтичні тощо), в ергономічному й естетичному вдосконаленні навколишкіх умов навчально-виховного процесу. Тому дефектолог заради корекції особистісного розвитку дітей з певними вадами повинен захопити їх будь-якою справою. На це здатний лише той педагог, який може загорітися й увійти у внутрішній світ кожного вихованця через його почуття. Тому така його якість, як позитивна емоційність породжує естетику трудових дій.

Це наштовхує на думку, що успіх корекційно-педагогічних трудових дій дефектолога залежить від високого рівня естетотерапевтичної компетентності, що, як доведено в дослідженні О. Федій, виконує такі функції, як: катарсичну (очищення емоційно-чуттєвої сфери людини від деструктивних переживань), саногенну (навчання позитивному конструктивному мисленню), гармонізуючу (налагодження гармонійних взаємин 3 природою й соціумом), творчо-стимулювальну (розвиток креативного потенціалу учасників педагогічної взаємодії), активізуючо-пізнавальну (активна жага до пізнання), нагромадження позитивного індивідуального досвіду (самотерапія, самоорганізація, позитивне соціальне контактування), духовного збагачення й зростання особистості (на аксіологічних засадах Життя, Любові, Добра й Світла) [4, с. 381-382].

А. Маркова справедливо стверджує, що педагогічна діяльність - це «технологія» праці вчителя, педагогічне спілкування - клімат і атмосфера цієї праці, а особистість - ціннісні орієнтації, ідеали, внутрішній зміст роботи вчителя. На думку психолога, професійна компетентність передбачає сформованість у праці вчителя всіх цих трьох складників [3, с. 6-7]. Відтак компетентний дефектолог першочергово має володіти корекційно-педагогічною технологією. При цьому слід зазначити, що термін «технологія» раніше пов'язували 3 виробничою сферою й по-суті охоплював сукупність методів обробки, виготовлення, зміни стану, властивостей, форми матеріалу, що застосовуються у процесі виробництва продукції. Згодом індустріальна революція зумовила проникнення технологізації й у сферу соціальних процесів, у тому числі й педагогічних. Отже, витоки терміна «технологія» мають виробничі корені. Але якщо зважати на те, що в грецькій мові слово «techne» означає мистецтво (відображення дійсності в конкретно-чуттєвих образах, відповідних до певних естетичних ідеалів; досконале вміння в якійсь справі, галузі; майстерність), то корекційно-педагогічну технологію правомірно зараховувати до категорій, що має естетичну сутність. На нашу думку, вона полягає в сукупності алгоритмізованих трудових дій, спрямованих на профілактику, виправлення, усунення або нейтралізацію основних причин i умов, що зумовлюють дисгармонію особистісного розвитку дитини. Тобто, це поняття слід розуміти як процес планування й послідовне виконання трудових дій дефектолога для досягнення конкретних естетичних результатів. Це починається зі створення приємної, радісної атмосфери навчання, виховання й розвитку дітей, що на думку видатного чеського дидакта Я. Коменського $є$ 
необхідною умовою плідної праці вчителя. Він цілком слушно вважав, що педагог може бути корисним тоді, коли він радує вихованців, а його праця здійснюється з любов'ю [2].

Висновки. Таким чином, розглянуті вище аспекти вказаної проблеми повинні знайти належне осмислення в сучасній педагогічній практиці. Майбутні вчителі-дефектологи у процесі професійної підготовки повинні отримати необхідні знання, вміння та навички для виховання $\mathrm{i}$ навчання дітей з особливими потребами.

\section{ЛІТЕРАТУРА}

1. Еспаев Я. Ж. Педагогическая естетика: единство многообразия [Електронний ресурс]. - Режим доступу до ресурсу: http://arunet.kg/stati/76-pedagogicheskaya-estetika-edinstvo-mnogoobraziya. html.

2. Окушко Т. К. Соціально-педагогічні умови корекції девіантної поведінки підлітків у позашкільних навчальних закладах: автореф. дис. на здобуття наук. ступеня канд. пед. наук: спец. 13.00 .05 «Соціальна педагогіка» / Т. К. Окушко. - К., 2009. - 20 с.

3. Синьов В. Нова стратегія розвитку корекційної педагогіки в Україні / В. Синьов, А. Шевцов // Дефектологія. - 2004. - № 2. - С. 6-11.

4. Федій О. А. Функціонально-процесуальні засади естетотерапевтичної компетентності сучасного педагога / О. А. Федій // Педагогічні науки : теорія, історія, інноваційні технології. - Суми: СумДПУ ім. А. С. Макаренка, 2011. - №1 (11) - С. 380-389.

5. Maksymchuk, I., Maksymchuk, B., Frytsiuk, V., Matviichuk, T., Demchenko, I., Babii, I. ... Savchuk, I. (2018). Developing pedagogical mastery of future physical education teachers in higher education institutions. Journal of Physical Education and Sport, 18 (2), 810-815. Режим доступу до ресурсу: http://efsupit.ro/images/stories/iunie2018/Art 119.pdf

6. Shenaar-Golan, V. Hope and subjective well-being among parents of children with special needs (2017) Child and Family Social Work, 22 (1), pp. 306-316. 